
\title{
3 Research Suare \\ The effect of Zinc Oxide Nanoparticles on Pseudomonas Aeruginosa Biofilm Formation and Virulence Genes Expression
}

wedad abdelraheem ( $\nabla$ altaqwa.2012@yahoo.com )

Minia University Faculty of Medicine

Ebtisam S. Mohamed

Minia University Faculty of Medicine

\section{Research article}

Keywords: biofilm, expression, P.aeruginosa, rt-PCR, ZnO - np

Posted Date: July 9th, 2020

DOI: https://doi.org/10.21203/rs.3.rs-36749/v1

License: (c) (i) This work is licensed under a Creative Commons Attribution 4.0 International License.

Read Full License

Version of Record: A version of this preprint was published at The Journal of Infection in Developing Countries on June 30th, 2021. See the published version at https://doi.org/10.3855/jidc.13958. 


\section{Abstract}

Background: Due to increased resistance to antimicrobial agents, infectious disease remains a public health problem worldwide.

Aim: The current study was designed to examine the effect of $\mathrm{ZnO}$ nanoparticles ( $\mathrm{ZnO}-\mathrm{np}$ ) against the biofilm formation ability of P.aeruginosa clinical isolates and to study its effect on the expression level of the genes involved in biofilm formation and virulence factors production.

Methodology: The MIC of $\mathrm{ZnO}$ - np against $P$. aeruginosa was determined by the broth microdilution method. The Effect of $\mathrm{ZnO}-\mathrm{np}$ on the biofilm-forming isolates of $P$. aeruginosa was monitored by the microtiter plate method. P.aeruginosa isolates were tested for the expression of different biofilm and virulence genes using real-time rt-PCR.

Results: $\mathrm{ZnO}$-np significantly downregulated the expression level of all biofilm and virulence genes of P.aeruginosa clinical isolates except the tox $A$ gene.

Conclusions: This study demonstrates the promising use of $\mathrm{ZnO}-\mathrm{np}$ as an anti-biofilm and anti-virulence compound.

\section{Background}

P.aeruginosa is an important cause of community and hospital-acquired infections, especially in immunecompromised patients. The formation of biofilm by Paeruginosa is the key to its chronic colonization in human tissues. Due to the many clinical implications, biofilms formed by P.aeruginosa are the most frequently studied biofilm models [1].

Bacteria within biofilm shows marked resistance to antibiotics, reduction in growth rates and secretion of different surface molecules and virulence factors, which can enhance their pathogenicity by several hundred folds [2].

Increased resistance to antimicrobial agents is a major public health problem worldwide [3]. One of the most promising strategies for overcoming microbial resistance is the use of nanoparticles [4]. The exact mechanisms of action of nanoparticles are not yet known, it may be dependent on factors such as composition, surface changes, properties and concentration of nanoparticles [3].

One of the famous nanoparticles is $\mathrm{ZnO}-\mathrm{np}$ which is one of metal oxide nanoparticles. Zinc oxide is a polar inorganic compound. It appears as a white powder, nearly insoluble in water with many applications, such as antimicrobial, wound healing, UV filtering properties, high catalytic and photochemical activity, due to its unique combination of interesting properties such as selective toxicity toward bacteria, with minimal effects on human and animal cells, stability in a hydrogen plasma atmosphere and low price [5]. 
$\mathrm{ZnO}$ disrupts membrane integrity via the production of reactive oxygen species that destroy bacteria [6]. In addition, the production of hydrogen peroxide and $\mathrm{Zn}^{2+}$ has shown a key role in the antibacterial activity of nanoparticles [7].

However pathogenic microorganisms are able to protect themselves against inhibitory compounds by the formation of biofilms [8]. Therefore, the current study was designed to examine the effect of $\mathrm{ZnO}$-np against the biofilm formation ability of P.aeruginosa clinical isolates and to study its effect on the expression level of the genes involved in biofilm formation and virulence factors production of P.aeruginosa clinical isolates.

\section{Methods}

Written informed consents were obtained from all individuals. The study was approved by the Ethical Committee of Minia University, Faculty of Medicine (code number: 32 A).

\subsection{Bacterial strains}

The study was carried out on 100 biofilm-forming $P$. aeruginosa clinical isolates obtained from different clinical samples from different patients at Minia University Hospital. P. aeruginosa PAO1 as standard biofilm-producing strain and P1A isolate as non-biofilm producing strain were included as positive and negative controls respectively.

\subsection{Determination of minimum inhibitory concentration (MIC) and minimum bactericidal concentration (MBC)}

$\mathrm{ZnO}$ nanoparticles (20 $\pm 5 \mathrm{~nm}$ diameter) were purchased from Sigma-Aldrich. In order to examine the antibacterial activity of the $\mathrm{ZnO}-\mathrm{np}, \mathrm{ZnO}$-np were suspended in sterile normal saline and constantly stirring until a uniform colloidal stock suspension was formed at a concentration of $1024 \mu \mathrm{g} / \mathrm{ml}$. The stock suspensions were stored at $4 \mathrm{C}$. Before each experiment stock suspensions were stirred for $\mathrm{a} \sim 2 \mathrm{~h}$. The MIC of $\mathrm{ZnO}$-np against $P$. aeruginosa was determined by using the broth microdilution method in 96 well microplates according to CLSI guidelines. Serial dilutions were prepared in 10 wells with concentrations of $512,256,128,64,32,16,8,4,2$ and $1 \mu \mathrm{g} / \mathrm{ml}$ and two wells were positive (including culture media and microbial suspension) and negative (including culture media) controls. Then, 10 microliters of bacterial suspension (OD620 $=0.01)$ were added to wells containing different concentrations of nanoparticles and the plates were then incubated overnight at $37^{\circ} \mathrm{C}$. MIC is the lowest concentration of the nanoparticles that inhibit visible bacterial growth. The concentration of $\mathrm{ZnO}-\mathrm{np}$ that inhibited $50 \%$ and $90 \%$ of the isolates were measured as MIC50 and MIC90. The minimum bactericidal concentration was established by the lack of growth after re-inoculation from $\mathrm{ZnO}$-np-treated media to agar medium without nanoparticles. All experiments were carried out three times [9].

\subsection{Effect of $\mathrm{ZnO}-\mathrm{np}$ on biofilm formation:}


The Effect of $\mathrm{ZnO}$-np on the biofilm-forming isolates of $P$. aeruginosa was monitored by the microtiter plate method according to Samet et al instructions [10]. Briefly, $190 \mu$ l of bacterial suspension (OD620 = 0.01 ) in Luria Bertani broth was inoculated in 96 microtiter plates. Sub-MIC concentrations of ZnO-np were added to each well excluding the positive and negative control wells. Plates were incubated at $37^{\circ} \mathrm{C}$ for $24 \mathrm{hr}$. After incubation, the content of each well was gently removed. The wells were washed with phosphate-buffered saline solution to remove free-floating bacteria. Biofilms formed by bacteria were air and heat-fixed for one hour and stained with crystal violet $(0.1 \%, w / v)$. Excess stain was rinsed off by washing with water and plates were kept for drying. Ethanol $95 \%$ was added to the wells and after 15 minutes the optical densities (OD) of stained adherent bacteria were determined with ELISA reader (model $\mathrm{CS}$, Biotec) at $590 \mathrm{~nm}$. These OD values were considered as an index of bacteria adhering to surface and forming biofilms. Experiments were performed in triplicate, the data were then averaged.

\subsection{Effect of $\mathrm{ZnO}-\mathrm{np}$ on preformed biofilm}

Individual wells of microplates were filled with $190 \mu \mathrm{l}$ of bacterial suspension (OD620 $=0.01)$. The MTPs were incubated for $24 \mathrm{~h}$ at $37^{\circ} \mathrm{C}$. After incubation, $10 \mu \mathrm{l}$ of $\mathrm{ZnO}$-np dilutions were added to each well. The effect of $\mathrm{ZnO}$ nanoparticles on the preformed biofilms was tested after 2,4 or 6 hours incubation at $37^{\circ} \mathrm{C}$. The content of the microplates was gently removed at the end of the estimated time period and then examined as described above, OD of stained adherent bacteria in wells were read at $590 \mathrm{~nm}$.

\subsection{Effect of $\mathrm{ZnO}-\mathrm{np}$ on relative genes expression:}

P.aeruginosa isolates were tested for the expression of different biofilm and virulence genes using realtime reverse transcriptase-polymerase chain reaction (rt-PCR) according to the following steps.

\subsubsection{RNA extraction:}

Pure bacteria were inoculated in two tubes containing $2 \mathrm{ml}$ LB broth. One of the tubes contained no nanoparticles and the other had $\mathrm{ZnO}$-np. The $\mathrm{ZnO}$-np concentration used herein was determined based on MIC and MBC results so that was less than MBC concentration (19). Tubes were incubated at $37^{\circ} \mathrm{C}$, shaking $200 \mathrm{rpm}$ for 6 hours (19). Bacterial RNA was extracted by the Direct-zol RNA extraction kit (Zymo research CORP, Australian) according to the manufacturer's instructions. Absorbance was assessed by a spectrophotometer (Genova, USA), and the ratio of absorbance at $260 \mathrm{~nm}$ and $280 \mathrm{~nm}$ was used to assess the purity of the extracted RNA. The result within the 1.8 to 2 range was considered as acceptable purity. The quality of the extracted RNA was evaluated via electrophoresis on $1.2 \%$ agarose gel at $100 \mathrm{~V}$ for 60 min.

\subsubsection{Rt-PCR}

According to manufacturer instructions quantitative real-time rt-PCR was done using one step Sybr green kits (SensiFAST SYBR Lo-ROX Kit, Meridian Life science, UK) in an ABI 7500 instrument (Applied Biosystems, USA). Real-time rt-PCR reaction was prepared with a final volume $20 \mu$ (master mix: $10 \mu$, Forward primer: $0.8 \mu$, Reverse primer: $0.8 \mu$, Reverse transcriptase: $0.2 \mu$, RNase inhibitor, $0.4 \mu$, Water up 
to $16 \mu$ and Template: $4 \mu$ ). Different genes and primers were listed in Table 1. Four negative control samples contain deionized water instead of template, one for each gene were included in the same PCR run.

We analyzed PCR results with relative quantification to pro $C$ (housekeeping gene) as a reference gene thus standards with known concentrations are not required. We calculated the fold changes of mRNA levels using the comparative cycle threshold $(\Delta \Delta \mathrm{Ct})$. The fold change in gene expression was normalized to the reference gene ( pro $C$ ) and relative to the control sample. Then the relative expression was confirmed by using free data analysis tools [11]. PCR products were analyzed by gel electrophoresis, to exclude any unspecific products are present.

Table 1

List of primers used for amplification

\begin{tabular}{|c|c|c|}
\hline Gene & Primer sequence & Reference \\
\hline \multirow[t]{2}{*}{ Las $R$} & 5'-AAGTGGAAAATTGGAGTGGAG-3' & [11] \\
\hline & 5'-GTAGTTGCCGACGATGAAG-3' & \\
\hline \multirow[t]{2}{*}{$r h l l$} & 5'-GTAGCGGGTTTGCGGATG-3' & [12] \\
\hline & 5'-CGGCATCAGGTCTTCATCG-3' & \\
\hline \multirow[t]{2}{*}{$p q s R$} & 5'-CTGATCTGCCGGTAATTGG-3' & [12] \\
\hline & 5'-ATCGACGAGGAACTGAAGA-3' & \\
\hline \multirow[t]{2}{*}{$\operatorname{Lec} A$} & 5'CACCATTGTGTTTCCTGGCGTTCA-3' & [13] \\
\hline & 5'-AGAAGGCAACGTCGACTCGTTGAT-3' & \\
\hline \multirow[t]{2}{*}{ Pel A } & 5'-AAGAACGGATGGCTGAAGG-3' & [14] \\
\hline & 5'-TTCCTCACCTCGGTCTCG-3' & \\
\hline \multirow[t]{2}{*}{ toxA } & $5^{\prime}$...GACAACGCCCTCAGCATCAACAGC & [14] \\
\hline & 5'...CGCTGGCCCATTCGCTCCAGC & \\
\hline \multirow[t]{2}{*}{ exos } & $5^{\prime}$...AGGCATTGCCCATGACCTTG & [14] \\
\hline & 5'...ATACTCTGCTGACCTCGCTC & \\
\hline \multirow[t]{2}{*}{ lasA } & TTCTGTGATCGATTCGGCTCGGTT & [13] \\
\hline & ACCCGGGAAGACAACTATCAGCTT & \\
\hline \multirow[t]{2}{*}{ Pro $c$} & 5'CAGGCCGGGCAGTTGCTGTC-3' & [15] \\
\hline & 5'-GGTCAGGCGCGAGGCTGTCT-3' & \\
\hline
\end{tabular}

\subsubsection{Statistical Analysis}


All statistical analyses were performed using the SPSS program for Windows (version 20 statistical software; Texas instruments, IL, USA). A two-tailed $p$-value of $\otimes 0.05$ was considered statistically significant.

\section{Results}

\subsection{ZnO nanoparticles MIC and MBC:}

The results of the broth microdilution method showed that MIC50 and MIC90 of ZnO -np that inhibits the growth of $p$. aeruginosa clinical isolates were 64 and $128 \mu \mathrm{g} / \mathrm{ml}$, respectively. The range of MIC of ZnO nanoparticles for $P$. aeruginosa clinical isolates were $8-128 \mu \mathrm{g} / \mathrm{ml}$. Anti-bacterial activity increased with the rising concentration of $\mathrm{ZnO}$ nanoparticles as shown in Fig. 1. The MBC of nanoparticles that kill 50 and $100 \%$ of the isolates were 128 and $256 \mu \mathrm{g} / \mathrm{ml}$ respectively.

(Fig. 1: MIC of ZnO -np: $X$ axis represent serial dilutions of $Z n o-n p$ that was sudied in this study. $Y$ axis represent the percent of the inhibited bacterial isolates at each concentration. The percent of the inhibited isoaltes increased ith rising $\mathrm{ZnO}-\mathrm{np}$ concentration.)

\subsection{Antibiofilm effect of $\mathrm{ZnO}$ nanoparticles}

ZnO -np showed anti-biofilm activity on all tested isolates. The anti-biofilm activity increased with the rising concentration of nanoparticles as shown in Fig. 2. BIC50 and BIC90 (biofilm inhibitory concentration in 50 and $90 \%$ of the isolates respectively) were 16 and $32 \mu \mathrm{g} / \mathrm{ml}$ respectively.

(Fig. 2: BIC of ZnO -np: $X$ axis represent serial dilutions of $Z n o-n p$ that was sudied in this study. $Y$ axis represent the percent of the inhibited bacterial biofilms at each concentration. The percent of the inhibited bacterial biofilms increased ith rising $\mathrm{ZnO}-\mathrm{np}$ concentration.)

\subsection{Effect of $\mathrm{ZnO}-\mathrm{np}$ on the preformed biofilm}

In this study, P. aeruginosa was employed to evaluate the effect of $\mathrm{ZnO}$-np on the removal of established biofilms. The OD at $590 \mathrm{~nm}$ shown in Fig. 3 corresponded to the amount of remaining attached biofilm biomass of $P$. aeruginosa isolates after 2, 4 and $6 \mathrm{~h}$ treatment with $\mathrm{ZnO}$-np. Treating the preformed biofilm with $\mathrm{ZnO}$-np resulted in significant OD reduction. The degree of reduction depends on the concentration of $\mathrm{ZnO}$-np and the time of incubation between preformed biofilms and $\mathrm{ZnO}$-np as shown in Fig. 3.Significant reduction on the OD value (mean $\pm S D=1 \pm 0.03$; P-value $=0.001$ ) was reported at $64 \mu \mathrm{g} / \mathrm{ml}$ concentration of $\mathrm{ZnO}-\mathrm{NP}$ for $2 \mathrm{~h}$ incubation. The degree of reduction on the OD value was highly significant at8, 16, 32 and $64 \mu \mathrm{g} / \mathrm{ml}$ concentrations of $\mathrm{ZnO}$-np incubated for 4 and 6 hours with the preformed biofilms (P-value $₫ 0.0001)$.

(Fig. 3: Anti-biofilm effect of $\mathrm{ZnO}-\mathrm{np}$ : The figure represents the degree of reduction of OD values after 2, $4,6 \mathrm{hs}$ incubation of preformed bacterial biofilms with $\mathrm{ZnO}-\mathrm{np}$ at $37^{\circ} \mathrm{C}$.)

\subsection{Effect of $\mathrm{ZnO}-\mathrm{np}$ on relative genes expression:}


The effect of $\mathrm{ZnO}$ nanoparticles on the expression of different genes responsible for biofilm and virulence factors production was studied by RT-PCR. ZnO nanoparticles significantly downregulated the expression level of all biofilm and virulence genes of P.aeruginosa clinical isolates except the tox $A$ gene which was up-regulated as shown in Fig. 4. The fold change decrease of the quorum sensing genes, Las $R$, rhll and pqsR after ZnO nanoparticles treatment were $10.4,6.3$ and 8.7 fold (P-value $₫ 0.0001$ ) respectively. ZnO nanoparticles down-regulated other genes responsible for biofilm formation; LecA and Pel $A$ genes by 4.7

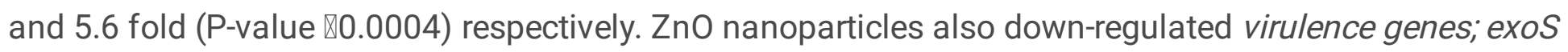
and las $A$ by 3.7 and 5.2 fold respectively (P-value $\varangle 0.008$ ). None statistically significant up-regulation of tox $A$ gene after $\mathrm{ZnO}$ nanoparticles treatment by 1.9 fold was reported ( $\mathrm{P}$-value $=0.37$ ).

(Fig. 4: Effect of $\mathrm{ZnO}$-np on relative genes expression: The figure represents the fold change decrease (-) or increase (+) in the virulence genes expression of $P$. aeruginosa clinical isolates after $\mathrm{ZnO}-\mathrm{np}$ treatment.)

\section{Discussion}

In our study, we have examined the antibacterial activity of $\mathrm{ZnO}-\mathrm{np}(20 \pm 5 \mathrm{~nm}$ diameter) and its effect on the biofilm formation by $P$. aeruginosa isolated from hospitalized patients.

In the present study, ZnO -np were found to be effectively inhibiting the growth of $P$. aeruginosa and restrict the biofilm formation.

The antibacterial and anti-biofilm effect gradually increased with raising the concentration of ZnO -np. MIC50 and MIC90 of ZnO -np for the studied isolates were 64 and $128 \mu \mathrm{g} / \mathrm{ml}$, respectively. BIC50 and $\mathrm{BIC90}$ of $\mathrm{ZnO}-\mathrm{np}$ for the studied isolates were 16 and $32 \mu \mathrm{g} / \mathrm{ml}$ respectively. The MBC of nanoparticles was higher than the MIC indicates that ZnO -NPs can kill bacteria at higher concentrations. Also, treating the preformed biofilm with $\mathrm{ZnO}$-np resulted in significant OD reduction.

$\mathrm{ZnO}$-np treatment resulted in a significant reduction in the OD value of the preformed biofilms at a concentration of $64 \mu \mathrm{g} / \mathrm{ml}$ for $2 \mathrm{~h}$ incubation. Also, a significant reduction was reported at lower concentrations for an extended time of incubation.

Overall, our results suggest that ZnO -np could inhibit the establishment and development of biofilm, also to remove pre-formed biofilm.

Some previous studies have shown the antibacterial activity of ZnO -np. Hosein Zadeh et al. have studied the antibacterial of $\mathrm{ZnO}$-np with the average of $20 \mathrm{~nm}$ against some bacteria, the MIC for $P$. aeruginosa isolates was $156.25 \mu \mathrm{g} / \mathrm{ml}$ [17].

Hassani et al. have studied the antibacterial and anti-biofilm effect of $\mathrm{ZnO}$-np with the average of $20 \mathrm{~nm}$ against $P$. aeruginosa clinical isolates; they reported that MIC50 and MIC90 of their studied isolates were $150 \mu \mathrm{g} / \mathrm{ml}$ and $175 \mu \mathrm{g} / \mathrm{ml}[18]$. 
Also, Hassani et al. reported that ZnO -np had an anti-biofilm effect at a concentration of 50 to $350 \mu \mathrm{g} /$ $\mathrm{ml}$. Also ZnO -np at a concentration of 100 to $350 \mu \mathrm{g} / \mathrm{ml}$ reduced pre-formed biofilm of $P$. aeruginosa [18].

Saadat et al. have studied the effect of $\mathrm{ZnO}$-np with the size of 30-90 $\mathrm{nm}$ against $P$. aeruginosa and reported that the mean MIC of $\mathrm{ZnO}-\mathrm{np}$ for the studied isolates was $300 \mu \mathrm{g} / \mathrm{ml}$ [19].

Pati et al showed that ZnO -np can disrupt bacterial cell membrane integrity, reduce cell surface hydrophobicity and down-regulate the transcription of oxidative stress-resistance genes in bacteria [20].

The toxicity of $\mathrm{ZnO}$ nanoparticles depends on concentration, bacterial species, and particle size [21].

We also assessed the relative expression of the genes regulating biofilm and other virulence factors production in $\mathrm{ZnO}$-treated and untreated isolates using the $\Delta \Delta \mathrm{Ct}$ method.

Lasl/R and rhll/R are two principle QS systems that regulate virulence genes production in Ps. aeruginosa. Las/ and rhl/ synthases are responsible for the production of C12-AHLand C4-AHL autoinducers, respectively. At a threshold concentration of autoinducers, C12-AHL binds with lasR and induces the expression of genes that control the production of elastase and proteases and also activates the rhll/R system. In addition, C4-AHL binds with $r h / R$ controlling the expression of genes encoding the production of elastase, and pyocyanin. If lasl/R and rhll/R are interrupted, virulence factors will be inhibited [22].

Our study reported that the relative expression levels of quorum sensing genes: las $R$, rhll, and $p q s R$ were significantly reduced under $\mathrm{ZnO}$ sub-MIC treatment.

The fold change decrease in the expression of lasR, rhll, and pqsR genes were 10.4, 6.3 and 8.7 fold (Pvalue $₫ 0.0001)$ respectively.

Adhesion factors are crucial for the attachment of bacterial cells to the surfaces. In $P$. aeruginosa biofilms, adhesion factors such as lectins (lecA and $l e c B$ ) play an important role in adhesion and biofilm formation.

In this study, ZnO nanoparticles significantly down-regulated $L e c A$ gene expression (P-value $\varangle 0.0004)$ in biofilm-forming $P$. aeruginosa clinical isolates by 4.7 fold change.

The presence of exopolysaccharides is an essential characteristic of the $P$. aeruginosa biofilm, which contributes to resistance and biofilm architecture. Pseudomonas biofilms are composed of at least three types of polysaccharides: Psl, Pel, and alginate. In the present study, the pelA gene was down-regulated in the presence of $\mathrm{ZnO}$ - np by 5.7 fold change (P-value $₫ 0.0004$ ) in biofilm-forming $P$. aeruginosa clinical isolates. In accordance with our data, Saleh et al. reported that ZnO-np had a significant decrease in the relative expression of QS-genes Iasl, lasR, rhll, rhIR, pqsA and pqsR. Additionally, ZnO significantly decreased the pathogenesis of P.aeruginosa in vivo [12]. 
Similarly, it was proved by Lee et al that ZnO $-\mathrm{np}(<50 \mathrm{~nm})$ inhibits $P$. aeruginosa biofilm formation and virulence factor production, they reported that $\mathrm{ZnO}$-np at $1 \mathrm{~mm}$ inhibited biofilm formation by more than $95 \%$ on polystyrene surface. Also, Lee et al. showed that $\mathrm{ZnO}-\mathrm{np}$ treatment resulted in significant regulation to most of the virulence genes of $P$. aeruginosa that were studied by microarray and qRT-PCR [23].

García-Lara et al. previously studied the effect of $\mathrm{ZnO}$ - np on the virulence factors production of clinical and environmental P.aeruginosa strains; they reported that $\mathrm{ZnO}$ - np were able to inhibit most virulence factors of the majority of the strains [24].

\section{Conclusion}

The results of our study showed that $\mathrm{ZnO}$ - $\mathrm{np}$ is highly effective against biofilm-forming $P$. aeruginosa isolates. In addition, this study also demonstrates the promising use of ZnO- np as an anti-biofilm QS inhibitor and anti-virulence compound. More studies are needed especially on animal models. Also, the possible harmful effects of ZnO- np should be investigated.

\section{Declarations}

\section{Ethical Approval}

Written informed consents were obtained from all individuals. The study was approved by the Ethical Committee of Minia University, Faculty of Medicine.

\section{Consent to publish}

The contents of this manuscript has not been published or submitted for publication elsewhere. Authors declare no conflicts of interest.

Declaration of interest: Authors declare no conflicts of interest.

Funding: This research did not receive any specific grant from funding agencies in the public, commercial, or not-for-profit sectors.

\section{Author contributions:}

Wedad conceived the study, perform the practical part, performed the data analysis, and drafted the manuscript. Ebtisam conceived the study purchased the required materials, assisted in performing the practical part and writing the manuscript.

\section{References}


1. Maita P. and Boonbumrung K. (2014): Association between biofilm formation of Pseudomonas aeruginosa clinical isolates versus antibiotic resistance and genes involved with biofilm. Journal of Chemical and Pharmaceutical Research. 6(5):1022-1028.

2. Hall-Stoodley L and Stoodley P. (2009): Evolving concepts in biofilm infections. Cell Microbiol 11(7):1034-1043

3. Kaplan JB, Ragunath C, Ramasubbu N and Fine DH (2003): Detachment of Actinobacillus actinomycetemcomitans biofilm cells by an endogenous b-hexosaminidase activity. J Bacteriol 185(16):4693-4698.

4. Cioffi N, Ditaranto N, Torsi L, Picca R, De Giglio E, Sabbatini L, Novello, L, Tantillo G, Bleve-Zacheo T and Zambonin P. (2005): Synthesis, analytical characterization and bioactivity of $\mathrm{Ag}$ and $\mathrm{Cu}$ nanoparticles embedded in poly-vinyl-methyl-ketone films. Anal. Bioanal. Chem; 382: 1912-1918.

5. Ennaoui A, Weber M, Scheer R and Lewerenz H. (1998): Chemical-Bath ZnO Buffer Layer for CulnS2 Thin- Film Solar Cells. Solar Energy Materials and Solar Cells; 54 (1-4): 277-286.

6. Khameneh B, Diab R, Ghazvini K and FazlyBazzaz B. (2016): Breakthroughs in bacterial resistance mechanisms and the potential ways to combat them. MicrobPathog; 95:32-42.

7. Diab R, Khameneh B, Joubert $O$ and Duval R. (2015): Insights in nanoparticle-bacterium interactions: new frontiers to bypass bacterial resistance to antibiotics. Curr Pharm Design; 21:4095-4105.

8. Huh AJ and Kwon YJ. (2011): "Nanoantibiotics": a new paradigm for treating infectious diseases using nanomaterials in the antibiotics resistant era. J Control Release; 156:128-145.

9. Clinical and Laboratory Standards Institute. (2015): Approved standard, CLSI document M100-S-25, Vol. 35No. 3. Wayne, PA, USA.

10. Samet M, Ghaemi E, Jahanpur S and Jamalli A. (2013): Evaluation of biofilm-forming capabilities of urinary Escherichia coli isolates in microtiter plate using two different culture media. International Journal Of Molecular And Clinical Microbiology; 3(1):244-7.

11. El-Khashaab T, Erfan D. M, and Kamal A. (2016): Pseudomonas Aeruginosa Biofilm Formation and Quorum Sensing lasR Gene in Patients with Wound Infection. Vol. 25. 101-108.

12. Saleh MM, Sadeq RA, Latif HKA, Abbas HA and Askoura M. (2019): Zinc oxide nanoparticles inhibits quorum sensing and virulence in Pseudomonas aeruginosa. Afr Health Sci; 19(2):2043-2055. doi:10.4314/ahs.v19i2.28.

13. Dosunmu E, Chaudhari A, Singh S, Dennis. and Pillai S. (2015): Silver-coated carbon nanotubes downregulate the expression of Pseudomonas aeruginosa virulence genes: a potential mechanism for their antimicrobial effect. Int $J$ Nanomedicine, 10, 5025-34.

14. Hassan R, Barwa R and Adel H. (2015): Comparison of some virulence factors and antimicrobial resistance associated genes of biofilm and non-biofilm producing pseudomonas aeruginosa. $\mathrm{N}$. Egypt. J. Microbiol. 37. 1-16.

15. Savli H, Karadenizli A, Kolayli F, Gundes S, Ozbek U and Vahaboglu H. (2003): Expression stability of six housekeeping genes: A proposal for resistance gene quantification studies of Pseudomonas aeruginosa by real-time quantitative RT-PCR. J Med Microbiol, 52, 403-8. 
16. Livak K and Schmittgen T. Methods. Vol. 25. San Diego C. (2001): Analysis of relative gene expression data using real-time quantitative PCR and the 2(-Delta Delta C(T)) Method; p. 402-408.

17. Hosein Zadeh E, Samargandi M, Alikhani M, Roshanaei G, Asgari G. (2012): Antimicrobial efficacy of zinc oxide nanoparticles suspension against Gram negative and Gram positive bacteria. IJHE; 5: 331342. 23. 23.

18. Hassani M, Moghaddam M and Forghanifard M. (2014): Inhibitory effect of zinc oxide nanoparticles on pseudomonas aeruginosa biofilm formation. Nanomedicine Journal. 6. 121-128

19. Saadat M, Roudbar S, Yadegari M, Eskandari M, and Khavari-nejad R. (2012): An assessment of antibacterial activity of ZnO nanoparticles, Catechin, and EDTA on standard strain of pseudomonas aeruginosa. JJUMS; 10: 13-19.

20. Pati R, Mehta RK, Mohanty S, Padhi A, Sengupta M and Vaseeharan B. (2014). Topical application of zinc oxide nanoparticles reduces bacterial skin infection in mice and exhibits antibacterial activity by inducing oxidative stress response and cell membrane disintegration in macrophages. Nanomedicine; 10(6): 1195-208.

21. Ma H, Williams P and Diamond S. (2013): Ecotoxicity of manufactured ZnO nanoparticles - a review. Environ Pollut 2013;172:76-85.

22. Parsek M, Val D, Hanzelka B, Val D, Hanzelka B, CronanJr J. (1999): Acyl-homoserine lactone quorum sensing signal generation. Proceedings of the National Academy of Sciences of the United States of America; 96:4360- 4365.

23. Lee J, Kim Y, Cho M and Lee J. (2014): ZnO nanoparticles inhibit Pseudomonas aeruginosa biofilm formation and virulence factor production. Microbiol Res.

24. García-Lara B, Saucedo M, Roldán-Sánchez J, Perez B, Mohankandhasamy R, Lee J, Coria-Jimén R, Tapia M, Varela-Guerrero V and García-Contreras R. (2015): Inhibition of quorum-sensing-dependent virulence factors and biofilm formation of clinical and environmental Pseudomonas aeruginosa strains by ZnO nanoparticles. Letters in applied microbiology.61. 10.1111/lam.12456.

\section{Figures}




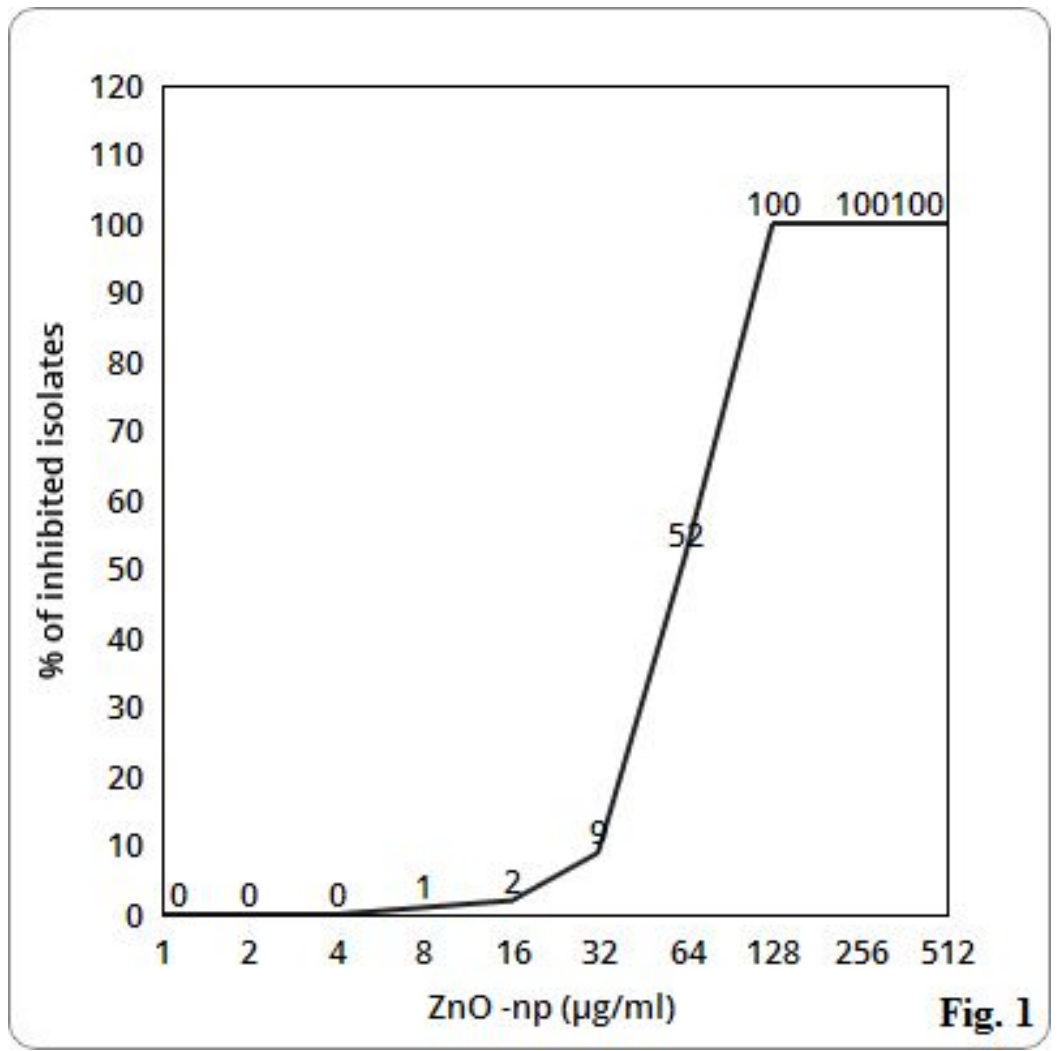

Figure 1

MIC of $\mathrm{ZnO}-\mathrm{np}$ : $\mathrm{X}$ axis represent serial dilutions of $\mathrm{Zno}-\mathrm{np}$ that was sudied in this study. $\mathrm{Y}$ axis represent the percent of the inhibited bacterial isolates at each concentration. The percent of the inhibited isoaltes increased ith rising $\mathrm{ZnO}-\mathrm{np}$ concentration.

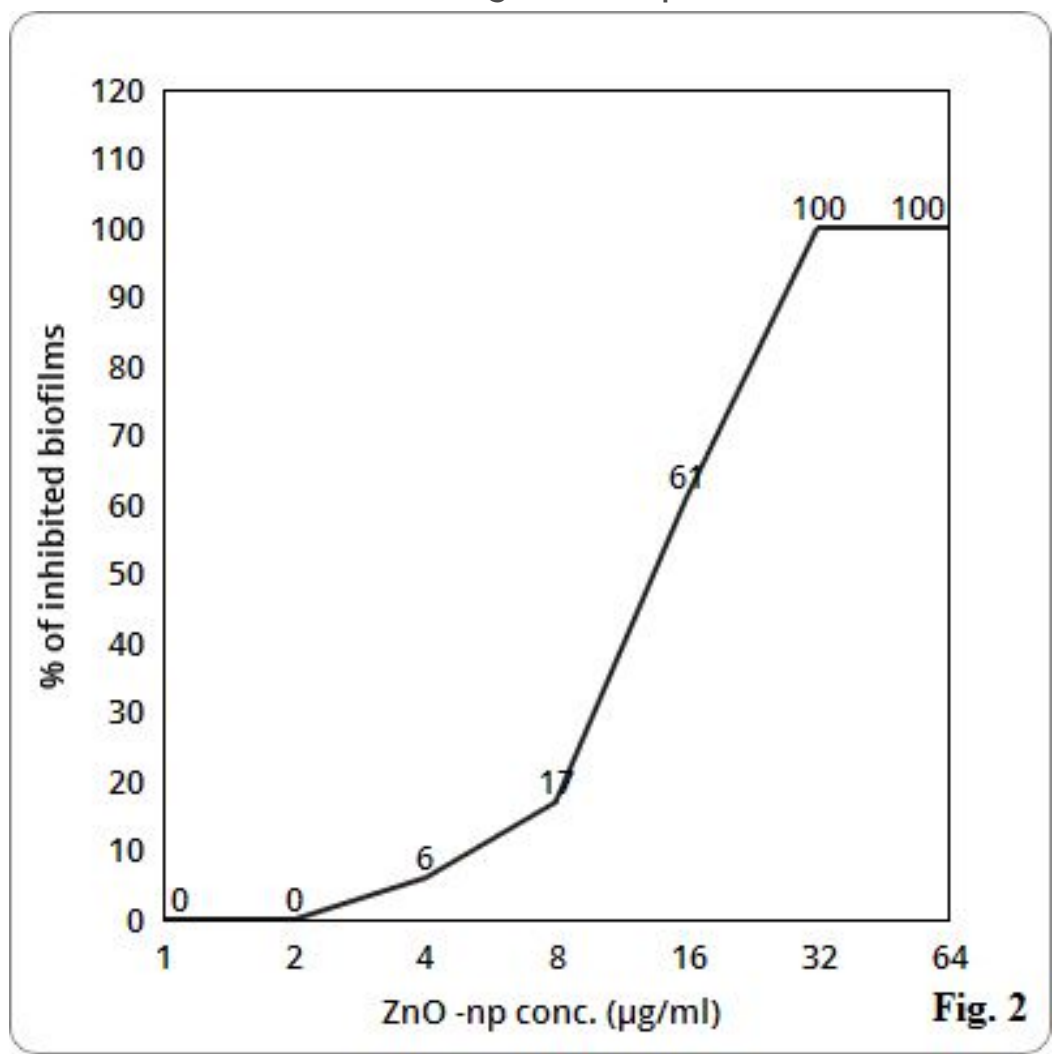


Figure 2

BIC of ZnO -np: $X$ axis represent serial dilutions of $Z n o-n p$ that was sudied in this study. $Y$ axis represent the percent of the inhibited bacterial biofilms at each concentration. The percent of the inhibited bacterial biofilms increased ith rising $\mathrm{ZnO}-\mathrm{np}$ concentration.

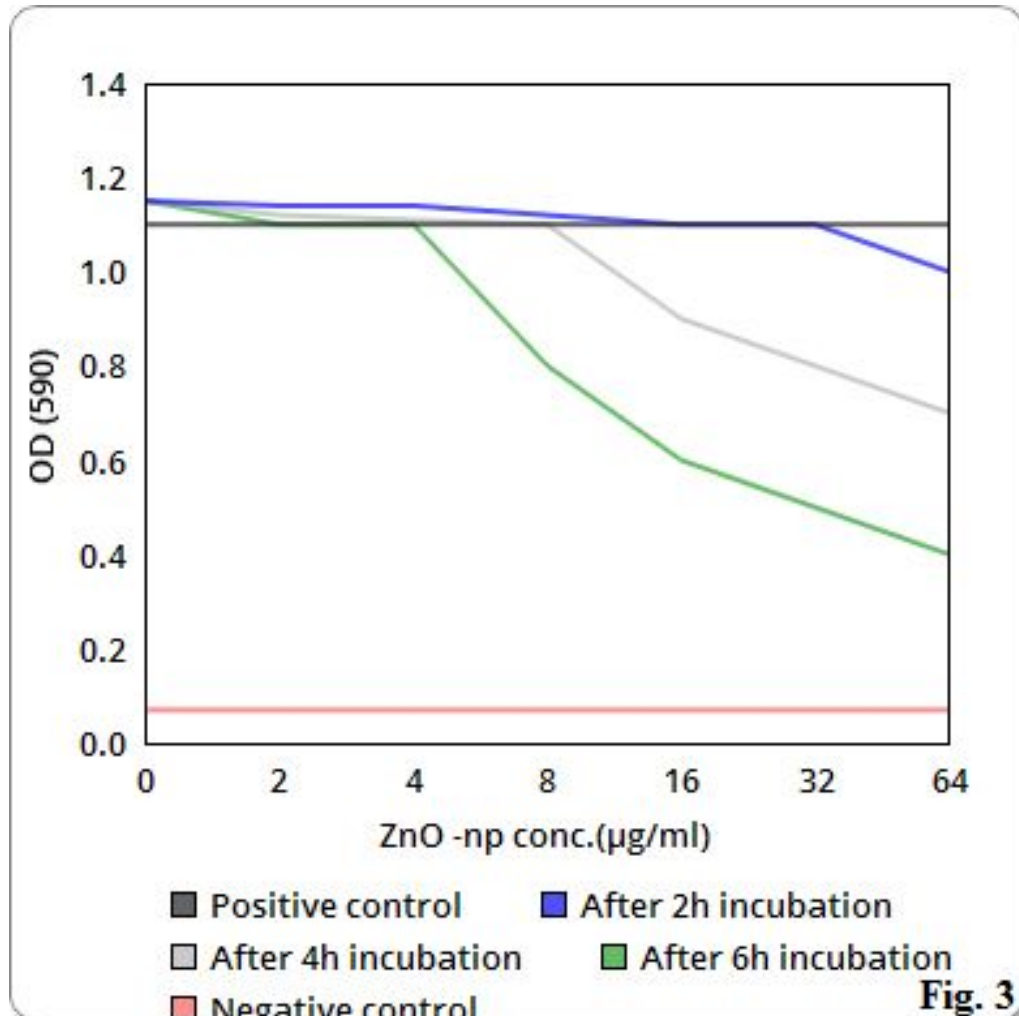

Figure 3

Anti-biofilm effect of $\mathrm{ZnO}$-np: The figure represents the degree of reduction of OD values after 2, 4, 6hs incubation of preformed bacterial biofilms with $\mathrm{ZnO}-\mathrm{np}$ at 37. Letter $\mathrm{S}$ represent significant reduction of $O D$ values at certain concentration for certain time of incubation. 


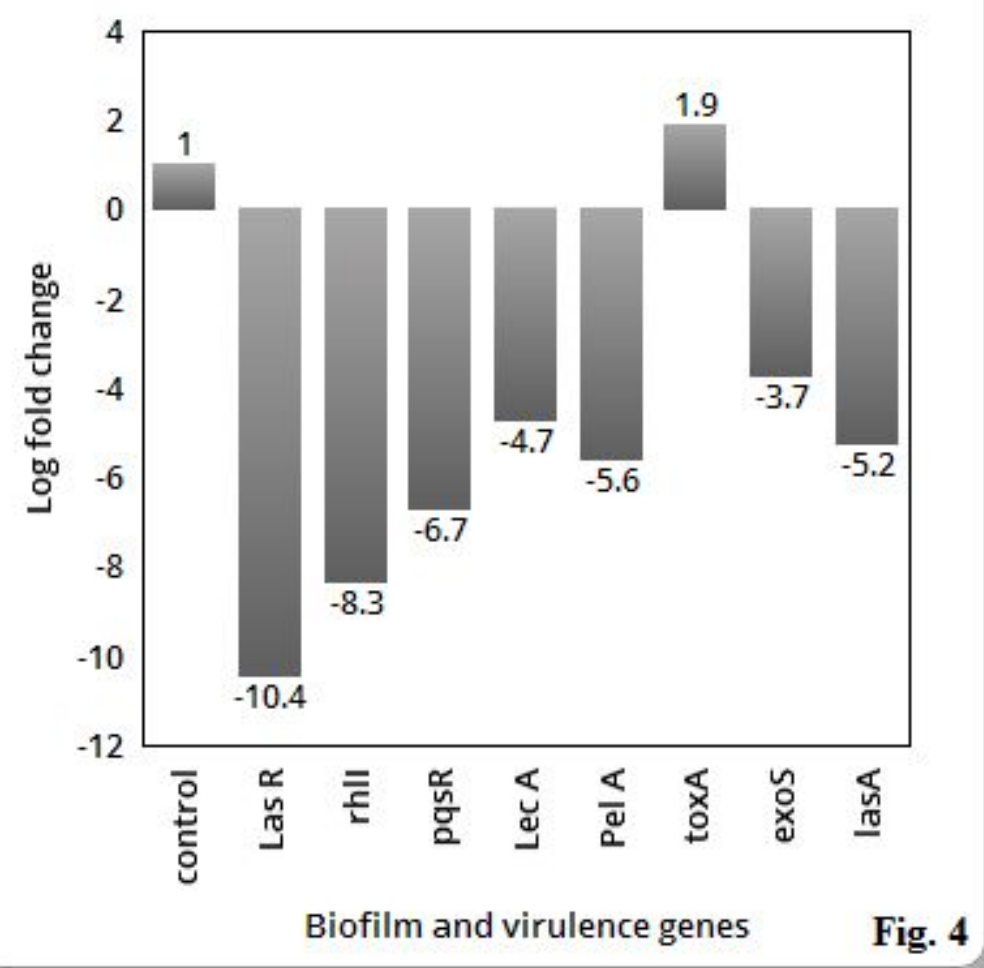

Figure 4

Effect of $\mathrm{ZnO}$-np on relative genes expression: The figure represents the fold change decrease (-) or increase $(+)$ in the virulence genes expression of $\mathrm{P}$. aeruginosa clinical isolates after $\mathrm{ZnO}-\mathrm{np}$ treatment. 